\title{
Synthesis and structures of ring and cage compounds containing Si-O-As bonds
}

\author{
George Ferguson, ${ }^{\mathrm{a}}$ Brian J. O’Leary, ${ }^{\mathrm{b}}$ and Trevor R. Spalding* \\ ${ }^{a}$ School of Chemistry, The University, St. Andrews, Fife KY16 9ST, ${ }^{b}$ Department of Chemistry, \\ University College Cork, National University of Ireland, Cork, Ireland \\ E-mail GF: crystals@uoguelph.ca ; TRS: t.spalding@ucc.ie
}

Dedicated to Professor Tony McKervey on his retirement from Queen's University Belfast, Ireland

(received 07 Mar 03; accepted 03 Jun 03; published on the web 10 Jun 03)

\begin{abstract}
The cyclic arsenosilicate compounds $(\mathrm{PhAsO})_{2}\left(\mathrm{Bu}_{2}^{\mathrm{t}} \mathrm{SiO}\right)_{2}, 7,\{\mathrm{PhAs}(\mathrm{O}) \mathrm{O}\}_{2}\left(\mathrm{Bu}_{2}^{\mathrm{t}} \mathrm{SiO}\right)_{2}, \mathbf{8}$,

$\left[\mathrm{OCMe}_{2} \mathrm{CH}_{2} \mathrm{C}(\mathrm{H}) \mathrm{MeO}\right] \mathrm{AsOSiPh}_{3}, \mathbf{9}$, and cage-structured $\mathrm{Bu}^{\mathrm{t}} \mathrm{Si}\{\mathrm{OAs}(\mathrm{Ph}) \mathrm{O}\}_{3} \mathrm{SiBu}^{\mathrm{t}}, \quad \mathbf{1 0}$ and $\mathrm{As}\left(\mathrm{OSiBu}_{2}^{\mathrm{t}} \mathrm{O}\right)_{3} \mathrm{As}$, 11, have been synthesised, their spectroscopic (IR and NMR) and mass spectrometric properties recorded and the solid state structures of 7, $\mathbf{9}$ and $\mathbf{1 0}$ established with single crystal X-ray techniques.
\end{abstract}

Keywords: Arsenosilicate, synthesis, structures, X-ray, spectroscopy

\section{Introduction}

This paper discusses the synthesis and structural study of several new cyclic and cage-structured compounds which contain As-O-Si bonds. Compounds containing As-O-Si bonds are usually called "arsenosilicates" or "arsenosiloxanes" in general but As(III)-containing compounds may also be referred to as "silyl arsenites" whilst those containing As(V) are "silyl arsenates". The practical applications of arsenosilicates have largely been in the synthesis of siloxane-based polymers with antifungal properties, ${ }^{1,2}$ but more recently, the compound $\left[\mathrm{As}\left(\mathrm{OSiPh}_{2} \mathrm{O}\right)_{3} \mathrm{As}\right]$ has been used as an arsenic dopant for semiconductor manufacture. ${ }^{3}$

Knowledge of the crystal structures and detailed structural properties of molecular compounds containing As-O-Si bonds is meagre. ${ }^{4}$ Previously reported structures which do not contain transition element atoms include the $\mathrm{As}$ (III) compounds $\mathrm{As}\left(\mathrm{OSiPh}_{3}\right)_{3} \mathbf{1},{ }^{5}$ and $\mathrm{As}\left(\mathrm{OSiPh}_{2} \mathrm{O}\right)_{3} \mathrm{As} 2{ }^{6}$, and the $\mathrm{As}(\mathrm{V})$ species $\left(\mathrm{Me}_{3} \mathrm{SiO}\right)_{8} \mathrm{As}_{4} \mathrm{O}_{6} \mathbf{3}^{7}\left(\mathrm{Me}_{3} \mathrm{SiO}\right)_{2}(\mathrm{PhNH}) \mathrm{AsO}$ 4, $\left(\mathrm{Me}_{3} \mathrm{SiO}\right)_{3} \mathrm{AsO} \cdot\left(\mathrm{Me}_{3} \mathrm{SiO}\right)_{3} \mathrm{AsNMe}{ }^{8}{ }^{8}$ and $\left[\left(\mathrm{Me}_{3} \mathrm{SiO}\right)_{2} \mathrm{AsN}\right]_{3}$ 6. $^{9}$ All of the compounds of $\mathrm{As}(\mathrm{V})$ involve the As-OSiMe $\mathrm{O}_{3}$ moiety and, 
except for 4, they all contain cyclic core structures, i.e. $\left\{\mathrm{As}_{4} \mathrm{O}_{6}\right\}$, $\{\mathrm{AsOAsN}\}$ and $\left\{\mathrm{As}_{3} \mathrm{~N}_{3}\right\}$ respectively.

Consideration of bond length and angle data from compounds $\mathbf{1}$ - $\mathbf{6}$ shows that the As-O and Si$\mathrm{O}$ distances are notably constant irrespective of the form of the compound or oxidation state of arsenic. Thus reported distances for As-O bonds range from 1.728(2) $\AA$ in 1 to 1.781(3) $\AA$ in 2 and Si-O bonds range from 1.628(4) $\AA$ in 2 to 1.655(2) $\AA$ in 1. Also, the As-O-Si angle appears to be relatively inflexible irrespective of whether the species contains $\mathrm{As}(\mathrm{III})$ or $\mathrm{As}(\mathrm{V})$. Angles range from $128.5(4)^{\circ}$ in $\left[\left(\mathrm{Me}_{3} \mathrm{SiO}\right)_{2} \mathrm{AsN}\right]_{3}, \mathbf{6}^{9},{ }^{9}$ to $146.94(11)^{\circ}$ in $\mathrm{As}\left(\mathrm{OSiPh}_{3}\right)_{3} \mathbf{1}^{5}$ This range of angles may be compared with the much larger range of values for the siloxane Si-O-Si angle, which varies from 90 to $180^{\circ}$ in molecular species. ${ }^{10}$

The present work discusses the synthesis of the following new cyclic compounds: $(\mathrm{PhAsO})_{2}\left(\mathrm{Bu}_{2}^{\mathrm{t}} \mathrm{SiO}\right)_{2}, 7$, and $\{\mathrm{PhAs}(\mathrm{O}) \mathrm{O}\}_{2}\left(\mathrm{Bu}_{2}^{\mathrm{t}} \mathrm{SiO}\right)_{2} \mathbf{8}$, and the cage-structured species $\mathrm{Bu}^{\mathrm{t}} \mathrm{Si}\{\mathrm{OAs}(\mathrm{Ph}) \mathrm{O}\}_{3} \mathrm{SiBu}^{\mathrm{t}}, \mathbf{1 0}$, and $\mathrm{As}\left(\mathrm{OSiBu}_{2}^{\mathrm{t}} \mathrm{O}\right)_{3} \mathrm{As}, \mathbf{1 1}$, and reports an alternative synthesis of :

$\left[\mathrm{OCMe}_{2} \mathrm{CH}_{2} \mathrm{C}(\mathrm{H}) \mathrm{MeO}\right] \mathrm{AsOSiPh}_{3}, \mathbf{9}^{11}$

The solid state structures of $\mathbf{7 , 9}$ and $\mathbf{1 0}$ were established, and the results extend the knowledge of As-O-Si bond parameters.

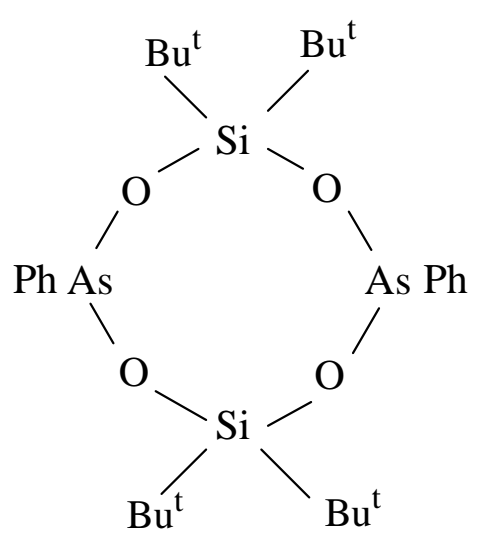

7

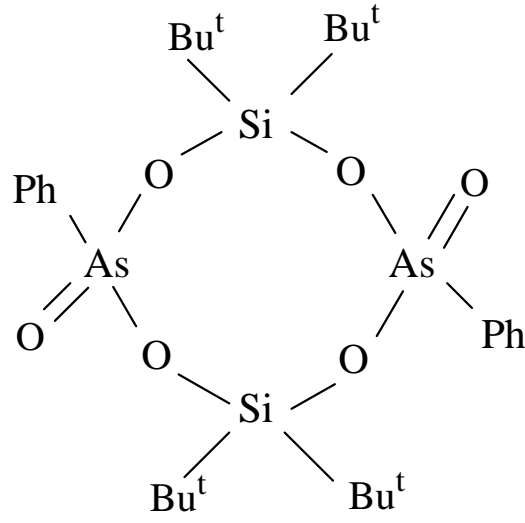

8

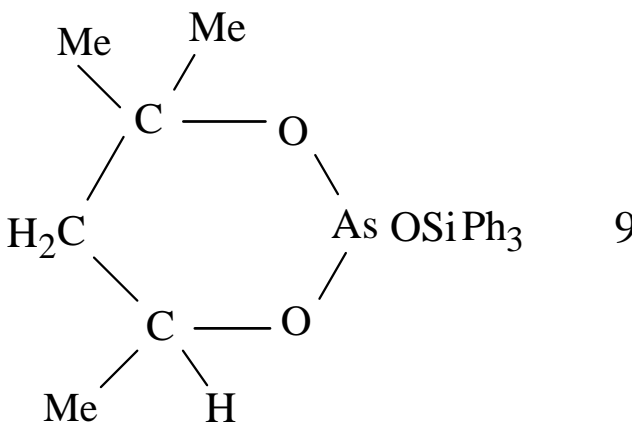




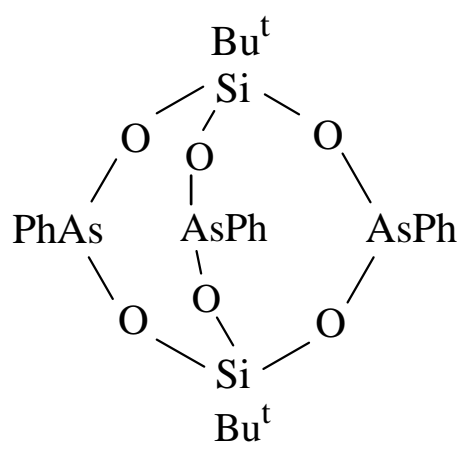

10

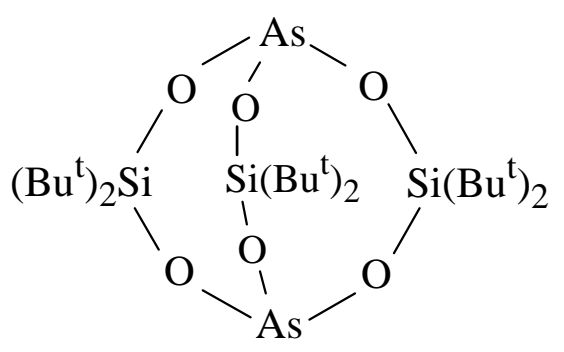

11

\section{Results and Discussion}

Solid State Structures of Compounds 7, 9 and 10.

Structural study of $(\mathrm{PhAsO})_{2}\left(\mathrm{Bu}_{2}^{\mathrm{t}} \mathrm{SiO}\right)_{2}, 7$

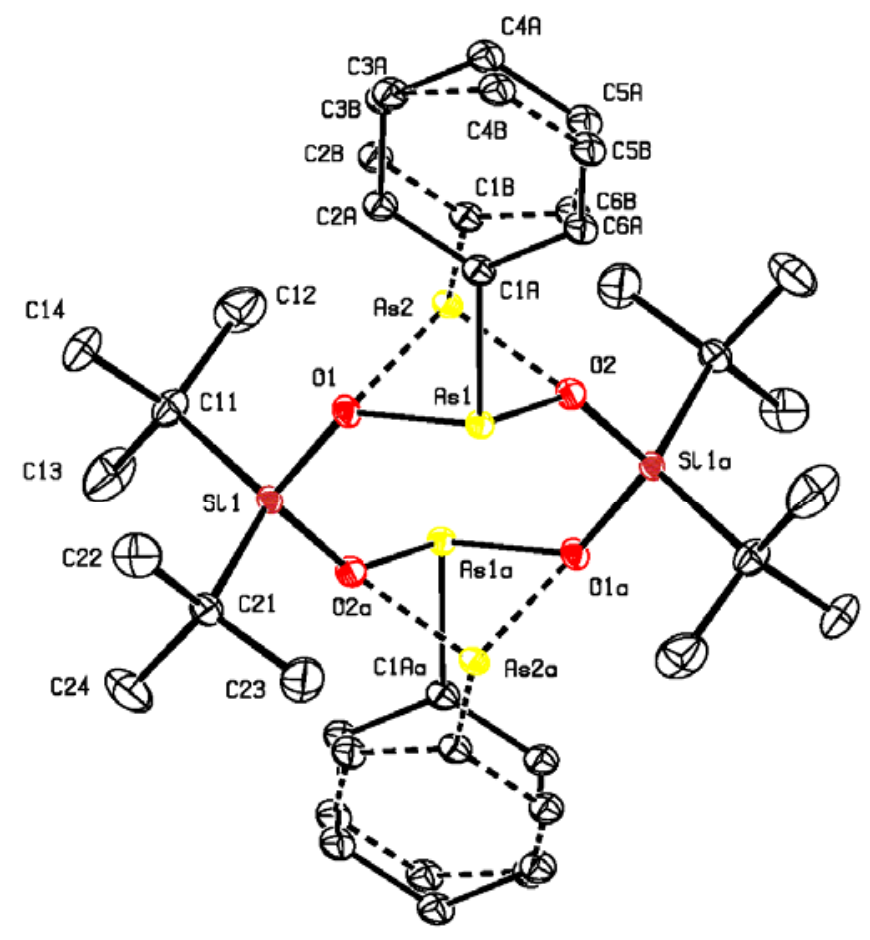

Figure 1 
Structure of $(\mathrm{PhAsO})_{2}\left(\mathrm{Bu}_{2}^{\mathrm{t}} \mathrm{SiO}\right)_{2}, 7$. The unique $\mathrm{Ph}$-As moiety is disordered over two sites such that the structure consists of two conformers, $\boldsymbol{A}$ (ca. 78\%) and $\boldsymbol{B}$ (ca. 22\%). Atoms labelled as As1, As1a and CnA atoms refer to conformer $\boldsymbol{A}$, whilst the As2, As2a and $\mathrm{CnB}$ atoms refer to conformer B. All other atoms are common to both conformers. For clarity, ellipsoids are shown

The molecule of 7 lies about an inversion centre and contains two trigonal pyramidal $\mathrm{AsO}_{2} \mathrm{C}$ - units bridged by two tetrahedral $-\mathrm{OSiBu}_{2}^{\mathrm{t}} \mathrm{O}$ - groups to form an eight-membered $\{\mathrm{As}-\mathrm{O}-\mathrm{Si}-\mathrm{O}\}_{2}$ heterocycle which adopts a "chair-like" conformation.. The unique Ph-As moiety is disordered unequally over two sites. This was allowed for during the structure refinement ${ }^{12}$ and the occupancies of the disordered groups refined to $0.775(2) / 0.225(2)$. The nature of the disorder in 7 is shown in Figure 1. Principal dimensions for the major conformer of 7 are in Table 1.

Table 1. Bond Length and Bond Angle Data for the Major (ca. 78\%) Conformer of $(\mathrm{PhAsO})_{2}\left(\mathrm{Bu}_{2}^{\mathrm{t}} \mathrm{SiO}\right)_{2}, 7$.

\begin{tabular}{cclc}
\hline Bond & Bond Length/ $\AA$ & Bond & Bond Length/ $\AA$ \\
\hline As1-O1 & $1.781(3)$ & C11-C12 & $1.543(11)$ \\
As1-O2 & $1.789(3)$ & C11-C13 & $1.529(11)$ \\
As1-C1A & $1.949(3)$ & C11-C14 & $1.508(9)$ \\
Si1-O1 & $1.647(3)$ & C21-C22 & $1.539(9)$ \\
Si1-O2\# & $1.633(3)$ & C21-C23 & $1.506(9)$ \\
Si1-C11 & $1.877(6)$ & C21-C24 & $1.512(10)$ \\
Si1-C21 & $1.876(6)$ & &
\end{tabular}

\begin{tabular}{lclc} 
Bond Angle & Degrees & Bond Angle & Degrees \\
O1-As1-O2 & $98.0(2)$ & O1-As1-C1A & $94.9(2)$ \\
O1-Si1-O2\# & $110.3(2)$ & O2-As1-C1A & $95.7(2)$ \\
O1-Si1-C11 & $104.9(2)$ & C6A-C1A-As1 & $117.2(2)$ \\
O1-Si1-C21 & $109.0(2)$ & Si1-O1-As1 & $133.0(2)$ \\
O2\#-Si1-C21 & $104.5(2)$ & Si1\#-O2-As1 & $136.6(2)$ \\
C11-Si1-C21 & $118.2(3)$ & & \\
\hline
\end{tabular}

\# atom at equivalent position (-x, 1-y, 1-z). 
Only the data for the major conformer are discussed here; the values of the As-O-Si angles, $133.0(2)$ and $136.6(2)^{\circ}$, are similar and are within the previously reported range of 128.5(4) to $146.94(11)^{\circ}{ }^{5,9}$ Moreover, it is interesting to note that the chemical equivalence of the As-O-Si units in 7 does not lead to geometric equivalence of these linkages in the solid state. Other examples of this type of behaviour are to be found in 1 where the As-O-Si angles are 133.15(10), 144.12(11) and $146.94(11)^{\circ}$ and in other main group species including borosilicates e.g. the B-O-Si angles in $\mathrm{PhB}\left(\mathrm{OSiPh}_{3}\right)_{2}$ are 140 and $156^{\circ} .^{13}$ The Si-O(-As) distances in 7, 1.633(3) and 1.647(3) $\AA$, are slightly shorter than the corresponding distance of 1.654(9) $\AA$ in $\mathrm{Bu}_{2}{ }_{2} \mathrm{Si}(\mathrm{OH})_{2} .{ }^{14}$ The angles at arsenic are characteristic of pyramidal geometry. The O-As-C angles of the major conformer of 7 are very similar and have a mean value of $95.3^{\circ}$. The O-As-O angles may be compared with those in 2 for which a range of $97.72(17)$ to $100.64(18)^{\circ}$ and a mean value of $98.88^{\circ}$ were reported. ${ }^{6}$

The O-Si-O angle in 7 measures $110.3(2)^{\circ}$ and is notably larger than the corresponding angle, 106.0(5) ${ }^{\circ}$, in the precursor compound $\mathrm{Bu}_{2}^{\mathrm{t}} \mathrm{Si}(\mathrm{OH})_{2} \cdot{ }^{14}$ This larger angle in 7 may be a result of the constraints imposed by the presence of a cyclic system and a more comparable system may be the cage compound $\mathrm{As}\left(\mathrm{OSiPh}_{2} \mathrm{O}\right)_{3} \mathrm{As}, 2$, in which the mean $\mathrm{O}-\mathrm{Si}-\mathrm{O}$ angle is $111.1^{\circ}{ }^{6}$

Other dimensions are in accord with accepted values and there are no untoward intermolecular contacts. Full geometrical details are available from the CCDC.

\section{Structural study of $\quad\left[\mathrm{OCMe}_{2} \mathrm{CH}_{2} \mathrm{C}(\mathrm{H}) \mathrm{MeO}\right] \mathrm{AsOSiPh}{ }_{3}, 9$.}

The structure of 9 contains two crystallographically independent molecules ( $\boldsymbol{A}$ and $\boldsymbol{B}$ ) in the unit cell. Principal dimensions for both molecules, Table 2, are very similar and are in accord with accepted values. The two molecules differ in the orientation of the $\mathrm{Ph}_{3} \mathrm{SiO}$ - groups relative to the six-membered $\mathrm{C}_{3} \mathrm{AsO}_{2}$ ring (e.g. torsion angles O3-As1-O1-Si1 141.9(6) and $100.0(5)^{\circ}$ for the $\boldsymbol{A}$ and $\boldsymbol{B}$ molecules respectively and the corresponding torsion angles C21-Si1-O1-As1 100.1(6) and 146.4(5) ${ }^{\circ}$ ). Each molecule contains a trigonal-pyramidal $\mathrm{AsO}_{3}$ - unit bonded through one oxygen atom to a tetrahedral $-\mathrm{SiPh}_{3}$ group. The conformation of the six-membered $\mathrm{C}_{3} \mathrm{AsO}_{2}$ ring may be described as a "chair" in both molecules, with the oxygen atom of the $\mathrm{Ph}_{3} \mathrm{SiO}$ - moiety axial. Figure 2 gives views of the two molecules and shows the chair ring conformation.

The six O-As-O angles in 9 vary over a narrow range from $97.6(3)^{\circ}$ in $\boldsymbol{A}$ to $100.4(3)^{\circ}$ in $\boldsymbol{B}$ and have a mean value of $99.1^{\circ}$. This value is typical of pyramidal coordination at arsenic. The two endocyclic (C-)O-As-O(-C) angles [100.1(3) and 100.4(3) ${ }^{\circ}$ in $\boldsymbol{A}$ and $\boldsymbol{B}$, respectively] are only slightly larger than the four exocyclic (C-)O-As-O(-Si) angles [range, 97.6(3) to 99.2(3) ${ }^{\circ}$ ]. The four As-O(-C) distances in 9 agree within 3 x s.u., and range from 1.747(6) to 1.759(6) $\AA$ with a mean value of $1.753 \AA$. The two As-O(-Si) distances are slightly longer, at 1.763(5) and 1.769(5) $\AA$ [ mean $1.766 \AA$ ].

The angles at $\mathrm{Si}$, the $\mathrm{Si}-\mathrm{O}$ and $\mathrm{Si}-\mathrm{C}$ distances and the bond distances and angles in the 2-methyl2,4-pentanediol residue in $\mathbf{9}$ are normal ${ }^{15}$ 


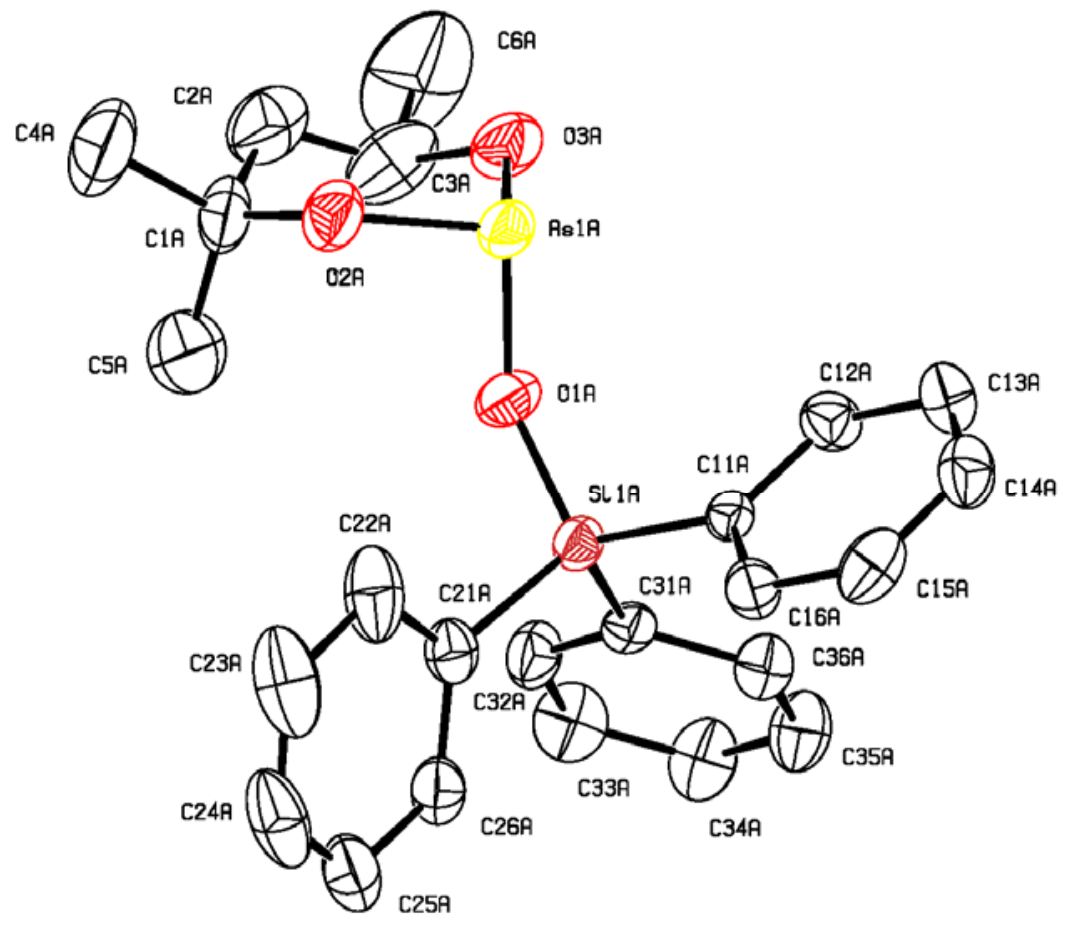

Figure 2a

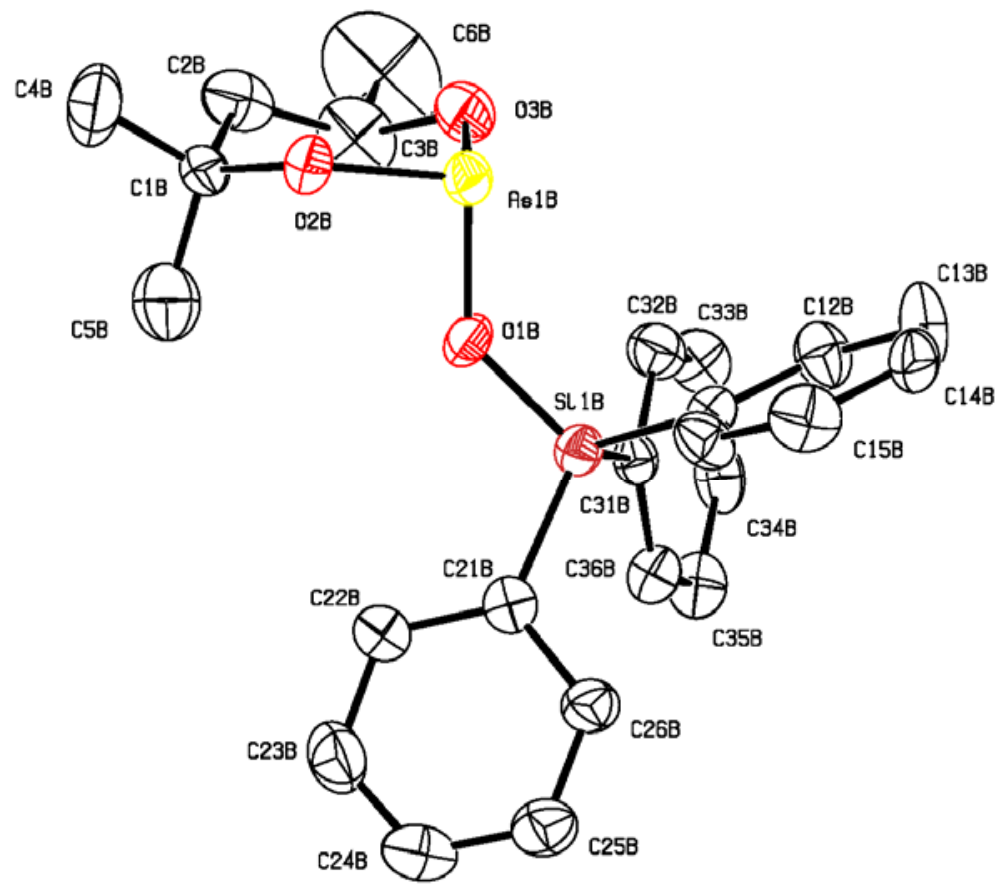

Figure 2b

Figure 2. Views of (a) molecule $\boldsymbol{A}$ and (b) molecule $\boldsymbol{B}$ of $\mathbf{9}$ showing the "chair" conformation. Ellipsoids are shown at the $30 \%$ probability level and $\mathrm{H}$ atoms are omitted for clarity. 
Table 2. Bond Length and Angle Data for the Two Conformers ( $A$ and $B$ ) of $9^{*}$

\begin{tabular}{cccc}
\hline Bond & Bond Length/ $\AA$ & Bond & Bond Length/ $\AA$ \\
\hline As1A-O1A & $1.769(5)$ & As1B-O1B & $1.763(5)$ \\
As1A-O2A & $1.747(6)$ & As1B-O2B & $1.752(5)$ \\
As1A-O3A & $1.759(6)$ & As1B-O3B & $1.753(6)$ \\
Si1A-O1A & $1.631(5)$ & Si1B-O1B & $1.652(5)$ \\
Si1A-C11A & $1.854(7)$ & Si1B-C11B & $1.856(8)$ \\
Si1A-C21A & $1.864(9)$ & Si1B-C21B & $1.858(8)$ \\
Si1A-C31A & $1.871(8)$ & Si1B-C31B & $1.885(8)$ \\
O2A-C1A & $1.469(12)$ & O2B-C1B & $1.471(9)$ \\
O3A-C3A & $1.432(13)$ & O3B-C3B & $1.448(12)$ \\
& & & \\
Bond Angle & Degrees & Bond Angle & Degrees \\
O1A-As1A-O2A & $99.2(3)$ & O1B-As1B-O2B & $98.2(2)$ \\
O1A-As1A-O3A & $97.6(3)$ & O1B-As1B-O3B & $99.0(3)$ \\
O2A-As1A-O3A & $100.1(3)$ & O2B-As1B-O3B & $100.4(3)$ \\
O1A-Si1A-C11A & $110.5(3)$ & O1B-Si1B-C11B & $110.3(3)$ \\
O1A-Si1A-C21A & $109.6(4)$ & O1B-Si1B-C21B & $109.0(3)$ \\
O1A-Si1A-C31A & $106.8(3)$ & O1B-Si1B-C31B & $109.0(3)$ \\
C11A-Si1A-C21A & $109.3(4)$ & C11B-Si1B-C21B & $109.4(3)$ \\
C11A-Si1A-C31A & $110.7(3)$ & C11B-Si1B-C31B & $110.5(3)$ \\
C21A-Si1A-C31A & $110.0(4)$ & C21B-Si1B-C31B & $108.6(4)$ \\
As1A-O1A-Si1A & $138.0(3)$ & As1B-O1B-Si1B & $134.1(3)$ \\
As1A-O2A-C1A & $122.3(6)$ & As1B-O2B-C1B & $123.4(5)$ \\
\hline As1A-O3A-C3A & $119.4(7)$ & As1B-O3B-C3B & $118.9(5)$ \\
\hline
\end{tabular}

Structural study of $\left[\mathrm{Bu}^{\mathrm{t}} \mathrm{Si}\{\mathrm{OAs}(\mathrm{Ph}) \mathrm{O}\}_{3} \mathrm{SiBu}^{\mathrm{t}}\right], 10$ 
Molecule 10 is severely disordered in the crystal structure and there was some $20 \%$ decay of standard intensities during data collection. However it was possible to determine details of the gross connectivity and conformation and establish the cage structure of $\mathbf{1 0}$. There are two independent $\left[\mathrm{Bu}^{\mathrm{t}} \mathrm{Si}\{\mathrm{OAs}(\mathrm{Ph}) \mathrm{O}\}_{3} \mathrm{SiBu}^{\mathrm{t}}\right]$ molecules present in the unit cell and each molecule has each $\mathrm{Ph}-\mathrm{As}$ group disordered in a similar manner to that observed in ( $\mathrm{PhAsO})_{2}\left(\mathrm{Bu}_{2}^{\mathrm{t}} \mathrm{SiO}\right)_{2}, 7$ above. In one molecule of 10 the Ph-As disorder was $0.67 / 0.33$ and in the other molecule the disorder ratio was $0.59 / 0.41$. A view of one of the molecules of $\mathbf{1 0}$ is shown in Figure 3a and a view of a disordered cage is in Figure $3 \mathrm{~b}$.

The analysis also confirmed the presence of a 1,2-dichloroethane solvent molecule in the asymmetric unit with 0.910ccupancy. Because of the poor quality and limited extent of the diffraction data a detailed discussion of the dimensions of $\mathbf{1 0}$ is not warranted.

\section{Conclusions}

Four new arsenasilicates, 7, 8, 10 and 11, have been prepared and characterised. Two, $(\mathrm{PhAsO})_{2}\left(\mathrm{Bu}_{2}^{\mathrm{t}} \mathrm{SiO}\right)_{2}, 7$ and $\{\mathrm{PhAs}(\mathrm{O}) \mathrm{O}\}_{2}\left(\mathrm{Bu}_{2}^{\mathrm{t}} \mathrm{SiO}\right)_{2}, \mathbf{8}$, contained (AsOSiO $\}_{2}$ rings with $\mathrm{As}(\mathrm{III})$ and $\mathrm{As}(\mathrm{V})$ atoms in $\mathbf{7}$ and $\mathbf{8}$ respectively. Compounds $\mathrm{Bu}^{\mathrm{t}} \mathrm{Si}\left\{\mathrm{OAs}(\mathrm{Ph}) \mathrm{O}_{3} \mathrm{SiBu}^{\mathrm{t}}\right.$, 10, and $\mathrm{As}\left(\mathrm{OSiBu}_{2}^{\mathrm{t}} \mathrm{O}\right)_{3} \mathrm{As}, \mathbf{1 1}$, were based on $\left\{\mathrm{Si}\{\mathrm{OAsO}\}_{3} \mathrm{Si}\right\}$ and $\left\{\mathrm{As}(\mathrm{OSiO})_{3} \mathrm{As}\right\}$ cages respectively.

Compound 9, [OCMe $\left.\mathrm{CH}_{2} \mathrm{C}(\mathrm{H}) \mathrm{MeO}\right] \mathrm{AsOSiPh}_{3}$, was a 1,3,2-dioxarsenane derivative with a $\left\{\mathrm{AsOC}_{2} \mathrm{O}\right\}$ ring. X-ray crystallographic techniques were used to study the solid state structures of 7, 9 and 10. The measured $\mathrm{As}-\mathrm{O}(\mathrm{Si})$ and $\mathrm{Si}-\mathrm{O}(\mathrm{As})$ bonds and As-O-Si angles in these compounds extend the known ranges of these parameters and confirm the flexibility of As-O-Si bonding. In single molecules of $\mathbf{7}$ there are significantly different As-O bond distances and As-O-Si angles even though the bonds are chemically equivalent, e.g. in conformer $\mathrm{B}$ the distances and angles are 1.801(4) and 1.889(4) $\AA$, and $123.4(2)^{\circ}$ and 134.7(2) . 


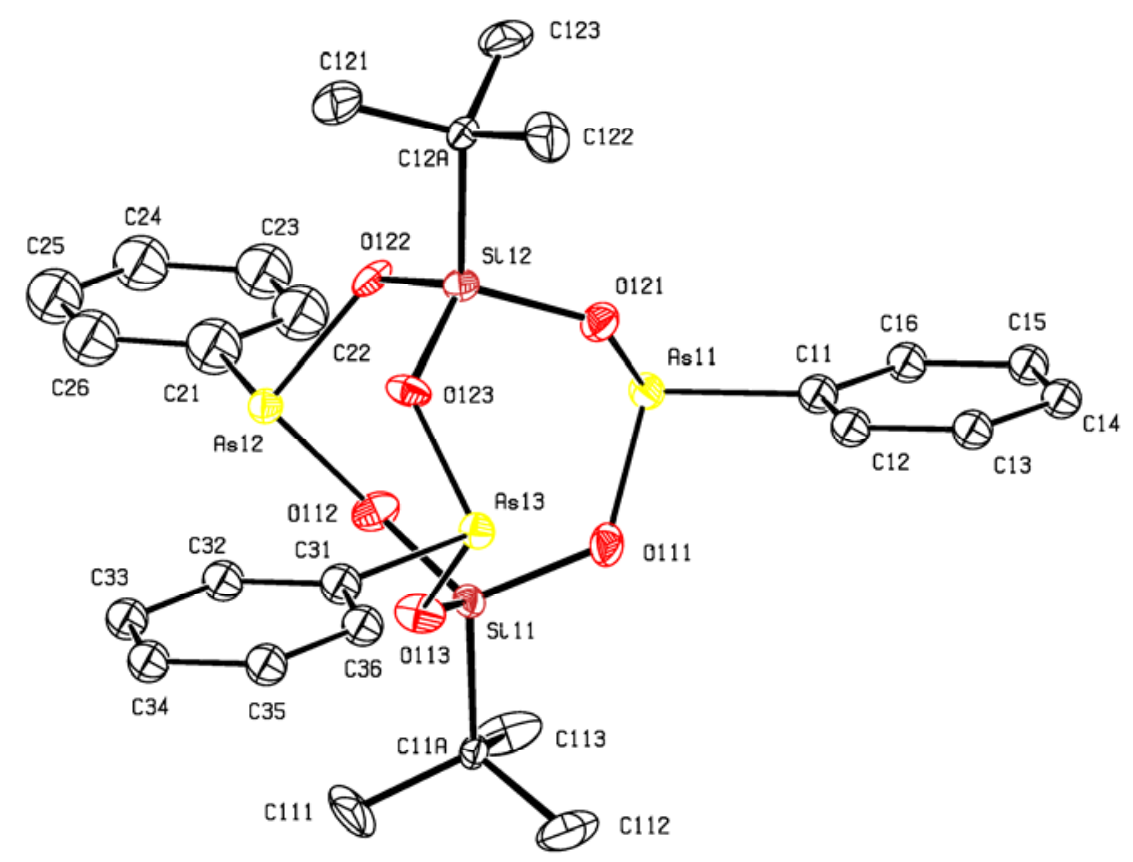

Figure 3a

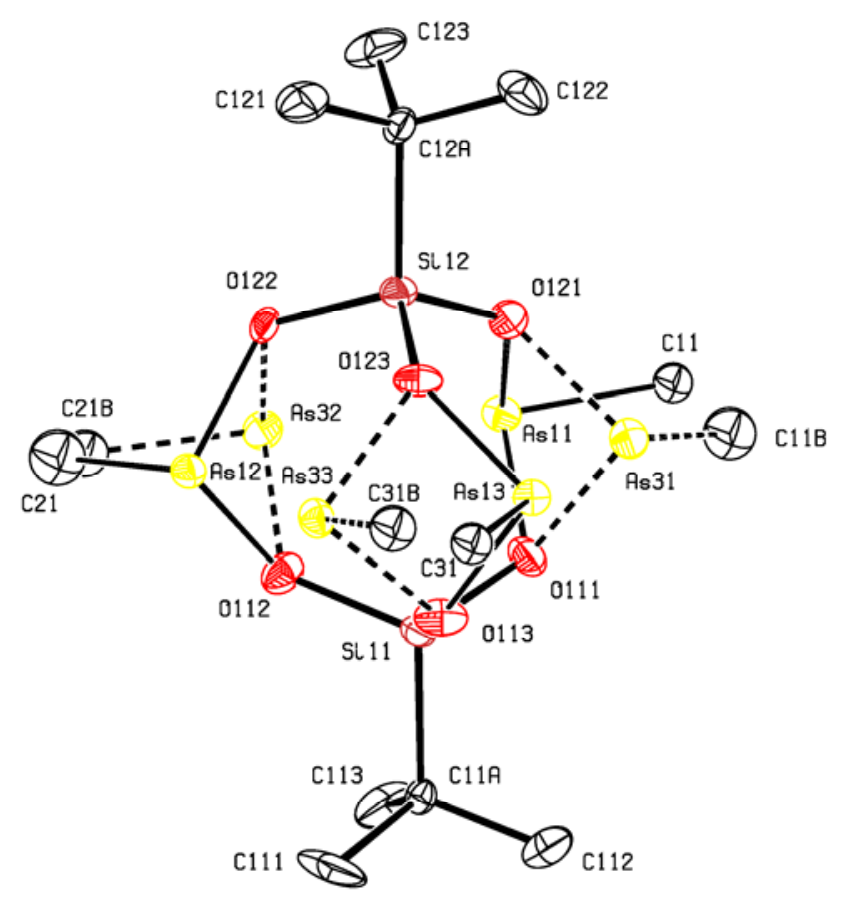

Figure 3b

Figure 3. (a) Structure of one of the molecules of $\left[\mathrm{Bu}^{\mathrm{t}} \mathrm{Si}\{\mathrm{OAs}(\mathrm{Ph}) \mathrm{O}\}_{3} \mathrm{SiBu}^{\mathrm{t}}\right], \mathbf{1 0}$. For clarity, the minor occupancy As-Ph groups and all $\mathrm{H}$ atoms have been omitted; ellipsoids are shown at the 10\% probability level. (b) A view of the same molecule showing some of the disorder; for clarity, only the first phenyl $\mathrm{C}$ atom is shown at each As atom and all $\mathrm{H}$ atoms have been omitted. 


\section{Experimental Section}

General Procedures. All reactions were carried out under an inert atmosphere. Solvents (supplied by Aldrich or Merck) were dried and distilled prior to use. Water was doubly distilled and deionised. The following reagents were used directly as supplied by the manufacturers: phenylarsine oxide, phenylarsonic acid, arsenic trichloride, triethylamine, diphenylsilanediol, [all Aldrich]. Di-tert-butylsilanediol and tert-butylsilanetriol were prepared from the corresponding diand tri-chloro compounds as described in references 14 and 16 respectively.

Infrared spectra in the range 4000-450 $\mathrm{cm}^{-1}$ were recorded on a Perkin Elmer Paragon 1000 Fourier Transform Spectrometer. Samples were prepared as $\mathrm{KBr}$ discs. All ${ }^{1} \mathrm{H}$ and ${ }^{13} \mathrm{C}$ NMR spectra were recorded on a JEOL FT NMR Spectrometer, G5X-270 Series. Tetramethylsilane, $\left(\mathrm{CH}_{3}\right)_{4} \mathrm{Si}$, was used as the standard and deuterated chloroform, $\mathrm{CDCl}_{3}$, as the solvent for all ${ }^{1} \mathrm{H}$ and ${ }^{13} \mathrm{C}$ spectra. All NMR spectra were recorded at ambient temperature. Mass spectra were recorded on a Kratos GC-MS High Resolution Mass Spectrometer. Melting points were recorded on an Electrothermal IA 9000 Series Digital Melting Point Apparatus. Elemental analyses were carried out on a Perkin Elmer 240C Elemental Analyser at the Microanalytical Laboratory, University College, Cork.

\section{Details of X-ray data collections, structure solutions and refinements}

Reflection data for 7, $\mathbf{9}$ and $\mathbf{1 0}$ were collected using a CAD4 diffractometer with Mo radiation and the data were corrected for Lorentz, polarization and absorption effects. Structure solution was by direct methods and refinement was by full-matrix least-squares calculations. Compound 7 has PhAs disorder (0.78/0.22) and the two unique As-C distance was restrained to be the same (1.943 $\AA$ ). Due to the extensive disorder in the structure of 7 the phenyl rings were treated as rigid hexagons with phenyl C-C distances and C-C-C angles set at $1.39 \AA$ and $120.0^{\circ}$, respectively. Analysis of compound 9 was straightforward with no untoward problems. For compound 10, freshly grown crystals were coated with epoxy cement to try to reduce solvent loss, but there was still some 20\% decay of standard reflection intensities and only $25 \%$ of the reflections were considered observed at the 2-sigma level. Nevertheless it was possible to determine the gross connectivity and the nature of the disorder of the Ph-As groups. For the refinement of 10, extensive use of DFIX restraints was made with e.g. Si-C 1.88, As-C $1.96 \AA$, all phenyl $\mathrm{C}$ atoms were only refined isotropically with phenyl C-C distances and C-C-C angles set at $1.39 \AA$ and $120.0^{\circ}$, respectively. Full details of the crystal structure data in CIF format have been deposited with the CCDC (reference numbers 205661, 205662 and 205663 for compounds 7, 9 and 10 respectively)

Synthesis of $(\mathbf{P h A s O})_{2}\left(\mathrm{Bu}_{2}{ }_{2} \mathrm{SiO}\right)_{2},(7)$. The As(III) compound 7 was prepared from the reaction between phenylarsenic oxide and di-tert-butylsilanediol. A solution of phenylarsine oxide (1.022 g, $6.08 \mathrm{mmol})$ and di-tert-butylsilanediol (1.072 g, $6.08 \mathrm{mmol})$ in toluene $(50 \mathrm{ml})$ was heated at reflux 
temperature for $20 \mathrm{~h}$. The solvent was removed leaving a viscous residue. Pumping under vacuum for $1 \mathrm{~d}$ gave a sticky off-white solid. Recrystallisation from warm $\mathrm{CH}_{2} \mathrm{Cl}_{2}$ afforded $\mathbf{7}$ as colourless crystals (1.629 g, 82.1\%), mp 207-208 ${ }^{\circ} \mathrm{C}$. Found: C, 51.60; H, 6.85\%. $\mathrm{C}_{28} \mathrm{H}_{46} \mathrm{As}_{2} \mathrm{O}_{4} \mathrm{Si}_{2}$ requires: C, 51.53; H, 7.10\%. FTIR (KBr disc), $\mathrm{v}_{\max } / \mathrm{cm}^{-1}:$ 2931(s), 959(vs), 900(vs), 827(s), 655(s). ${ }^{1} \mathrm{H}$ NMR ( $\mathrm{CDCl}_{3}$, p.p.m.): 7.79-7.70 [m, 4H, $\left.\mathrm{C}_{6} \underline{\underline{H}}_{5} \mathrm{As}\right] ;$ 7.51-7.25 [m, 6H, $\left.\mathrm{C}_{6} \underline{\mathbf{H}}_{5} \mathrm{As}\right] ; 1.08$ [s, 36H, $\left.\mathrm{C}\left(\mathrm{C}_{\mathbf{H}_{3}}\right)_{3}\right] .{ }^{13} \mathrm{C}$ NMR $\left(\mathrm{CDCl}_{3}\right.$, p.p.m.): 151.4, 130.4, 129.6, 128.9 [all $\left.\underline{\mathbf{C}}_{6} \mathrm{H}_{5} \mathrm{As}\right] ; 28.0\left[\mathrm{C}\left(\underline{\mathbf{C H}}_{3}\right)_{3}\right]$; $21.6\left[\underline{\mathrm{C}}\left(\mathrm{CH}_{3}\right)_{3}\right] . \mathrm{MS}(\mathrm{EI}), \mathrm{m} / \mathrm{z}: 652\left[(\mathrm{M})^{+}\right] ; 637\left[(\mathrm{M})^{+}-\mathrm{CH}_{3}\right] ; 595\left[(\mathrm{M})^{+}-\mathrm{Bu}^{\mathrm{t}}\right] ; 575\left[(\mathrm{M})^{+}-\mathrm{Ph}\right] ;$ $348\left[(\mathrm{M})^{+}-2 \mathrm{PhAs}\right] ; 152\left[(\mathrm{PhAs})^{+}\right]$.

Crystal data for 7. $\mathrm{C}_{28} \mathrm{H}_{46} \mathrm{As}_{2} \mathrm{O}_{4} \mathrm{Si}_{2}$, F.W. = 652.67, triclinic, $\mathrm{P} \overline{1}, a=8.2098(10) \AA, b=9.716(2) \AA$, $c=10.920(2) \AA, \alpha=73.939(16)^{\circ}, \beta=77.989(13)^{\circ}, \gamma=88.671(13)^{\circ}, \mathrm{V}=818.1(3) \AA^{3}, \mathrm{Z}=1, \mathrm{D}_{\mathrm{c}}=$

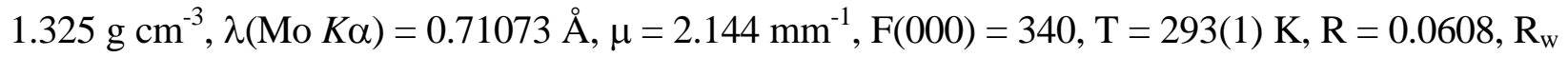
$=0.1653$ for 2250 observed reflections.

Synthesis of $\left\{\mathbf{P h A s}(\mathbf{O}) \mathbf{O}_{2}\left(\mathrm{Bu}_{2}^{\mathrm{t}}{ }_{2} \mathrm{SiO}\right)_{2},(\mathbf{8})\right.$. This $\mathrm{As}(\mathrm{V})$ derivative was prepared from the reaction between phenylarsonic acid and di-tert-butylsilanediol. A solution containing phenylarsonic acid (0.838 g, $4.15 \mathrm{mmol})$, di-tert-butylsilanediol $(0.731 \mathrm{~g}, 4.15 \mathrm{mmol})$ in toluene $(50 \mathrm{ml})$ was heated at reflux for $20 \mathrm{~h}$. The solvent was removed to leave a solid. Recrystallisation from a dichloromethane-cyclohexane (1:2) solution afforded $\mathbf{8}$ as a colourless crystalline solid (1.177 $\mathrm{g}$, 82.9\%), mp 276-279 ${ }^{\circ} \mathrm{C}$. Found: C, 48.89; H, 6.64\%. $\mathrm{C}_{28} \mathrm{H}_{46} \mathrm{As}_{2} \mathrm{O}_{6} \mathrm{Si}_{2}$ requires: C, 49.12; $\mathrm{H}$, 6.77\%. FTIR (KBr disc), $\mathrm{v}_{\max } / \mathrm{cm}^{-1}:$ 2935(s), 2861(s), 980(s), 933(vs), 828(s), 656(s). ${ }^{1} \mathrm{H}$ NMR ( $\mathrm{CDCl}_{3}$, p.p.m.): 7.70-7.62 [m, 4H, $\mathrm{C}_{6} \underline{\mathbf{H}}_{5} \mathrm{As}$ ]; 7.53-7.25 [m, 6H, $\left.\mathrm{C}_{6} \underline{\underline{H}}_{5} \mathrm{As}\right]$; 1.06 [s, 36H, C( $\left.\left(\underline{\mathrm{C}}_{3}\right)_{3}\right]$. ${ }^{13} \mathrm{C}$ NMR ( $\mathrm{CDCl}_{3}$, p.p.m.): 151.4, 130.5, 129.7, 128.9 [all $\left.\underline{\mathbf{C}}_{6} \mathrm{H}_{5} \mathrm{As}\right] ; 28.0\left[\mathrm{C}\left(\mathrm{CH}_{3}\right)_{3}\right] ; 21.7$ [ㅡ $\left.\left(\mathrm{CH}_{3}\right)_{3}\right] . \quad \mathrm{MS}(\mathrm{EI}), \mathrm{m} / \mathrm{z}: 684\left[(\mathrm{M})^{+}\right] ; 669\left[(\mathrm{M})^{+}-\mathrm{CH}_{3}\right] ; 627\left[(\mathrm{M})^{+}-\mathrm{Bu}^{\mathrm{t}}\right] ; 607\left[(\mathrm{M})^{+}-\mathrm{Ph}\right] ; 348$ $\left[(\mathrm{M})^{+}-2 \mathrm{PhAsO}\right] ; 168\left[(\mathrm{PhAsO})^{+}\right]$.

Compound $\mathbf{8}$ was also obtainable from the reaction between dichlorodiphenylsilane and di-tertbutylsilanediol in the presence of triethylamine. This reaction, which took place in refluxing toluene over 24 h, gave a yield of 8 after recrystallisation of $71 \%$.

\section{Synthesis of 4,4,6-trimethyl-2-(triphenylsiloxy)-1,3,2-dioxarsenane,}

$\left[\mathrm{OCMe}_{2} \mathrm{CH}_{2} \mathbf{C}(\mathbf{H}) \mathrm{MeO}\right] \mathrm{AsOSiPh}_{3}, 9$. This compound was previously prepared by the reaction between triphenylsilanol and the 2,2'-oxybis(4,4,6-trimethyl-1,3,2- dioxarsolane) in benzene solution. ${ }^{11}$ In the present study compound 9 was synthesised from the 'one-pot' reaction between triphenylsilanol, arsenic(III) oxide and 2-methyl-2,4-pentanediol in 2:1:2 mole ratio in benzene solution. A mixture of arsenic trioxide $(0.354 \mathrm{~g}, 1.79 \mathrm{mmol})$, triphenylsilanol $(0.975 \mathrm{~g}, 3.53 \mathrm{mmol})$ and 2-methyl-2,4-pentanediol $(0.416 \mathrm{~g}, 3.52 \mathrm{mmol})$ in benzene $(50 \mathrm{ml})$ was heated at reflux temperature for $15 \mathrm{~h}$. The solution was filtered and the solvent was removed leaving a solid. Recrystallisation from warm $\left(\mathrm{ca} .45^{\circ} \mathrm{C}\right.$ ) hexane afforded 9 as a crystalline colourless solid (1.419 g, 86.4\%), mp 94- $95^{\circ} \mathrm{C}$ (lit., ${ }^{100} 92^{\circ} \mathrm{C}$ ). Found: C, 61.95; H, 5.78\%. $\mathrm{C}_{24} \mathrm{H}_{27} \mathrm{AsO}_{3} \mathrm{Si}$ requires: C, 61.79; 
H, 5.83\%. FTIR (KBr disc), $\mathrm{v}_{\max } / \mathrm{cm}^{-1}:$ 1427(s), 1116(s), 896(vs), 876(vs), 846(s), 793(s), 712(vs), 699(s), 510(vs). ${ }^{1} \mathrm{H}$ NMR ( $\mathrm{CDCl}_{3}$, p.p.m.): 7.63-7.23 [m, 15H, $\left.\mathrm{C}_{6} \underline{\mathbf{H}}_{5} \mathrm{Si}\right]$; 4.71-4.46 [m, 1H, $\left.\mathrm{C} \underline{\mathbf{H}}\left(\mathrm{CH}_{3}\right)\right] ; 1.73-1.52\left[\mathrm{~m}, 2 \mathrm{H}, \underline{\mathrm{C}}_{2}\right] ; 1.33-1.15$ [m, 9H, $\left.\underline{\mathrm{H}}_{3}\right] .{ }^{13} \mathrm{C} \mathrm{NMR}\left(\mathrm{CDCl}_{3}\right.$, p.p.m.): 135.5, 129.9, 128.2, 127.8 [all $\left.\underline{\mathbf{C}}_{6} \mathrm{H}_{5}\right] ; 67.6\left[\underline{\mathrm{C}}\left(\mathrm{CH}_{3}\right)_{2}\right] ; 62.7\left[\underline{\mathrm{CH}}\left(\mathrm{CH}_{3}\right)\right] ; 46.1\left[\underline{\mathrm{CH}}_{2}\right] ; 33.5\left[\underline{\mathrm{CH}_{3}}\right] ; 29.5$ $\left[\underline{\mathrm{CH}}_{3}\right] ; 24.5\left[\underline{\mathrm{CH}}_{3}\right] . \mathrm{MS}(\mathrm{EI}), \mathrm{m} / \mathrm{z}: 466\left[(\mathrm{M})^{+}\right] ; 451\left[(\mathrm{M})^{+}-\mathrm{CH}_{3}\right] ; 408\left[(\mathrm{M})^{+}-\left(\mathrm{Me}_{2} \mathrm{C}=\mathrm{O}\right)\right] ; 389$ $\left[(\mathrm{M})^{+}-\mathrm{Ph}\right] ; 331\left[(\mathrm{M})^{+}-\mathrm{Ph}-\left(\mathrm{Me}_{2} \mathrm{C}=\mathrm{O}\right)\right] ; 199\left[\left(\mathrm{Ph}_{2} \mathrm{SiOH}\right)^{+}\right]$.

Crystal Data for 9. $\mathrm{C}_{24} \mathrm{H}_{27} \mathrm{AsO}_{3} \mathrm{Si}, \mathrm{F} . \mathrm{W} .=466.47$, monoclinic, $\mathrm{P} 2{ }_{1} / \mathrm{c}, a=13.134(2) \AA, b=$ 9.4216(14) $\AA, c=37.843(11) \AA, \beta=96.27(2)^{\circ}, V=4654.7(17) \AA^{3}, Z=8, D_{c}=1.331 \mathrm{~g} \mathrm{~cm}^{-3}, \lambda($ Mo $K \alpha)=0.71073 \AA, \mu=1.533 \mathrm{~mm}^{-1}, \mathrm{~F}(000)=1936, \mathrm{~T}=293(2) \mathrm{K}, \mathrm{R}=0.0581, \mathrm{R}_{\mathrm{w}}=0.1654$ for 3576 observed reflections.

Synthesis of $\mathrm{Bu}^{\mathrm{t}} \mathrm{Si}\left[\mathrm{OAs}(\mathrm{Ph}) \mathrm{O}_{3} \mathrm{SiBu}^{\mathrm{t}}\right.$, (10). Compound 10 was synthesised from the reaction between phenylarsenic oxide and tert-butylsilanetriol. Phenylarsine oxide (0.818 g, $4.87 \mathrm{mmol})$ and tert-butylsilanetriol (0.442 g, $3.24 \mathrm{mmol})$ were added to toluene $(50 \mathrm{ml})$ and the solution was heated at reflux for $16 \mathrm{~h}$. The solvent was removed to leave a viscous, off-white residue which became solid after pumping under vacuum for $2 \mathrm{~d}$. Recrystallisation from hot 1,2-dichloroethane afforded 10 as small rectangular colourless crystals (0.916 g, 78.1\%), mp 165-168 ${ }^{\circ} \mathrm{C}$. Crystals of 10 were ground into a fine white powder which was pumped under vacuum $\left(1 \mathrm{~mm} \mathrm{Hg}, 50^{\circ} \mathrm{C}\right)$ for 4 d prior to analysis. Found: C, 42.87; H, 4.66\%. $\mathrm{C}_{26} \mathrm{H}_{33} \mathrm{As}_{3} \mathrm{O}_{6} \mathrm{Si}_{2}$ requires: C, 43.22; H, 4.60\%. FTIR (KBr disc), $\mathrm{v}_{\max } / \mathrm{cm}^{-1}:$ 2956(m), 2936(m), 2858(m), 1474(m), 1435(m), 1232(m), 1086(m), 954(vs), 900(s), 736(m), 691(s), 622(m), 503(s). ${ }^{1} \mathrm{H} \mathrm{NMR}\left(\mathrm{CDCl}_{3}\right.$, p.p.m.): 7.81-7.77 [m, 6H, $\left.\mathrm{C}_{6} \underline{\mathbf{H}}_{5} \mathrm{As}\right] ;$ 7.52-7.25 [m, 9H, $\left.\mathrm{C}_{6} \underline{\mathbf{H}}_{5} \mathrm{As}\right] ; 1.02$ [s, $\left.18 \mathrm{H}, \mathrm{C}\left(\mathrm{C}_{3}\right)_{3}\right] .{ }^{13} \mathrm{C} \mathrm{NMR}\left(\mathrm{CDCl}_{3}\right.$, p.p.m.): 149.8, 130.2, 129.3, 128.4 [all $\left.\underline{\mathbf{C}}_{6} \mathrm{H}_{5}\right] ; 26.1\left[\mathrm{C}\left(\underline{\mathrm{CH}}_{3}\right)_{3}\right] ; 17.9$ [을 $\left.\left(\mathrm{CH}_{3}\right)_{3}\right] . \quad \mathrm{MS}(\mathrm{EI}), \mathrm{m} / \mathrm{z}: 722$ [(M) $\left.{ }^{+}\right] ; 07$ $\left[(\mathrm{M})^{+}-\mathrm{CH}_{3}\right] ; 665\left[(\mathrm{M})^{+}-\mathrm{Bu}^{\mathrm{t}}\right] ; 645\left[(\mathrm{M})^{+}-\mathrm{Ph}\right] ; 152\left[(\mathrm{PhAs})^{+}\right]$.

Crystal data for 10. $2\left(\mathrm{C}_{26} \mathrm{H}_{33} \mathrm{As}_{3} \mathrm{O}_{6} \mathrm{Si}_{2}\right) \cdot 0.91\left(\mathrm{C}_{2} \mathrm{H}_{4} \mathrm{Cl}_{2}\right)$. F.W. $=1534.97$, triclinic, $\mathrm{P} \overline{1}, a=$ 11.146(10) $\AA, b=17.489(8) \AA, c=19.346(10) \AA, \alpha=113.42(4)^{\circ}, \beta=101.07(5)^{\circ}, \gamma=91.84(5)^{\circ}, \mathrm{V}$ $=3371(4) \AA^{3}, \mathrm{Z}=2, \mathrm{D}_{\mathrm{c}}=1.515 \mathrm{~g} \mathrm{~cm}^{-3}, \lambda(\mathrm{Mo} \mathrm{K \alpha})=0.71073 \AA, \mu=3.137 \mathrm{~mm}^{-1}, \mathrm{~F}(000)=1550, \mathrm{~T}$ $=293(2) \mathrm{K}, \mathrm{R}=0.1050, \mathrm{R}_{\mathrm{w}}=0.2086$ for 2333 observed reflections.

Synthesis of $\mathbf{A s}\left(\mathrm{OSiBu}_{2}^{\mathrm{t}} \mathrm{O}\right)_{3} \mathrm{As}$, (11). Compound 11 is the di-tert-butyl analogue of the previously reported cage compound $\mathrm{As}\left(\mathrm{OSiPh}_{2} \mathrm{O}\right)_{3} \mathrm{As} \mathrm{2.}{ }^{3}$ It was prepared from the reaction between a solution of triethylamine in ether and an ice-cold mixture of arsenic trichloride and di-tert-butylsilanediol in ether.

Triethylamine (2.154 g, $21.29 \mathrm{mmol})$ in ether $(20 \mathrm{ml})$ was added dropwise over $30 \mathrm{~min}$. to an ice-cooled mixture of arsenic trichloride $(1.255 \mathrm{~g}, 6.92 \mathrm{mmol})$ and di-tert-butylsilanediol (1.842 g, $10.45 \mathrm{mmol})$ in ether $(40 \mathrm{ml})$. A precipitate formed immediately. The mixture was allowed to 
reach room temperature and stirred for $12 \mathrm{~h}$. The precipitate was removed by filtration and identified by infrared spectroscopy and elemental analysis (C, H, N) as [ $\left.\mathrm{HNEt}_{3}\right] \mathrm{Cl}$ (2.841 g, 99.4\%). Removal of solvent from the filtrate afforded a fluffy, colourless solid. Recrystallisation from cold $\left(-20^{\circ} \mathrm{C}\right)$ hexanes yielded 11 as clear rectangular crystals (2.007 g, 86.2\%), mp 230-233 ${ }^{\circ} \mathrm{C}$. Found: C, 42.47; H, 8.10\%. $\mathrm{C}_{24} \mathrm{H}_{54} \mathrm{As}_{2} \mathrm{O}_{6} \mathrm{Si}_{3}$ requires: C, 42.85; H, 8.09\%. FTIR (KBr disc), $\mathrm{v}_{\max } / \mathrm{cm}^{-1}$ : 2967(m), 2934(m), 2860(m), 1474(s), 1390(m), 1365(m), 914(vs), 858(vs), 826(s), 698(m), 655(s).

${ }^{1} \mathrm{H}$ NMR ( $\mathrm{CDCl}_{3}$, p.p.m.): 1.02 [s, C(C $\left.\left.\left.\left.\left.\underline{\mathrm{H}}_{3}\right)_{3}\right)\right] .{ }^{13} \mathrm{C} \mathrm{NMR}\left(\mathrm{CDCl}_{3} \text {, p.p.m.): } 27.2 \text { [C( } \underline{\mathrm{CH}}_{3}\right)_{3}\right)\right] ; 20.7$ [C $\left.\left(\mathrm{CH}_{3}\right)_{3}\right] . \mathrm{MS}(\mathrm{EI}), \mathrm{m} / \mathrm{z}: 615\left[(\mathrm{M})^{+}-\mathrm{Bu}^{\mathrm{t}}\right] ; 498\left[(\mathrm{M})^{+}-\mathrm{Bu}_{2}^{\mathrm{t}} \mathrm{SiO}_{2}\right]$.

\section{References}

1. Borisov, S.N.; Voronkov, M.G.; Lukevits, E.Ya. Organosilicon Derivatives of Phosphorus and Sulfur, Plenum Press: New York, 1971; Ch. 1 and refs. therein.

2. Chernyshev, E.A.; Bugerenko, E.F. Organomet. Chem. Rev. A 1968, 3, 469 and refs. therein.

3. Beyer, K.D. J. Electrochem. Soc. 1976, 123, 1556.

4. Allen, F.H. Acta Cryst. 2002, B58, 380.

5. Ferguson, G.; O'Leary, B.; Spalding, T.R. Acta Cryst. 1996, C52, 619.

6. Ferguson, G.; O'Leary, B.; Spalding, T.R. Acta Cryst. 1995, C51, 2312.

7. Baier, M.; Bissinger, P.; Schmidbaur, H.Chem. Ber. 1992, 125, 373.

8. Baier, M.; Paul, M.; Schmidbaur, H. Organometallics 1993, 12, 3527.

9. Baier, M.; Bissinger, P.; Schmidbaur, H. Chem. Ber. 1993, 126, 351.

10. Tailor-made Silicon-Oxygen Compounds, Corriu, R.; Jutzi, P. F., Eds; Vieweg \& Sohn: Braunschweig, F.R. Germany, 1996.

11. Pandey, J.N.; Srivastava, G. Silicon, Germanium, Tin and Lead Compounds 1986, 9, 41.

12. Sheldrick, G.M. SHELXL-97, University of Gottingen, Germany.

13. Murphy, D.; Sheehan, J.P.; Spalding, T.R.; Ferguson, G.; Lough, A.J.; Gallagher, J.F. J. Mater. Chem. 1993, 3, 1275.

14. Buttrus, N.H.; Eaborn, C.; Hitchcock, P.B.; Saxena, A.K. J. Organomet. Chem. 1985, 284, 291.

15. Allen, F.H.; Kennard, O.; Watson, D.G.; Brammer, L.; Orpen, A.G.; Taylor, R. J. Chem. Soc., Perkin Trans. II 1987, S1.

16. Winkhofer, N.; Roesky, H.W.; Noltemeyer, M.; Robinson, W.T. Angew.Chem. Int. Ed. Engl. 1992, 31, 599. 